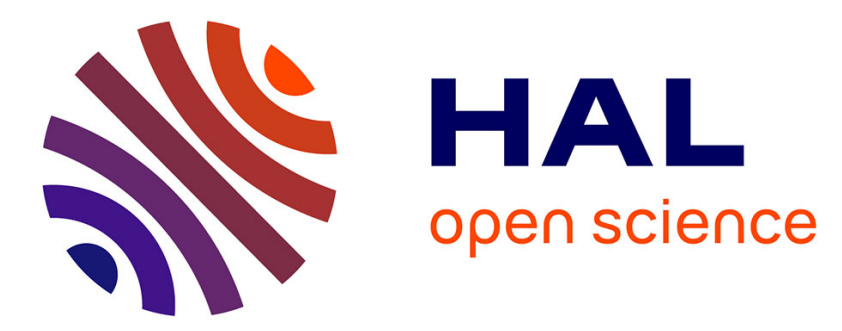

\title{
Unexpected Wind Power 'Potentials': The Art of Planning with Inherited Socio-Geographical Configurations (France)
}

Olivier Labussiere, Alain Nadaï

\section{- To cite this version:}

Olivier Labussiere, Alain Nadaï. Unexpected Wind Power 'Potentials': The Art of Planning with Inherited Socio-Geographical Configurations (France). Scottish Geographical Journal, 2014, 130 (3), pp.152 - 167. 10.1080/14702541.2014.922210 . hal-01785014

\section{HAL Id: hal-01785014 \\ https://hal-enpc.archives-ouvertes.fr/hal-01785014}

Submitted on 21 May 2018

HAL is a multi-disciplinary open access archive for the deposit and dissemination of scientific research documents, whether they are published or not. The documents may come from teaching and research institutions in France or abroad, or from public or private research centers.
L'archive ouverte pluridisciplinaire HAL, est destinée au dépôt et à la diffusion de documents scientifiques de niveau recherche, publiés ou non, émanant des établissements d'enseignement et de recherche français ou étrangers, des laboratoires publics ou privés. 


\title{
Unexpected Wind Power 'Potentials': The Art of Planning with Inherited Socio- Geographical Configurations (France)
}

\author{
OLIVIER LABUSSIERE ${ }^{\mathrm{a}} \&$ ALAIN NADAI $^{\mathrm{b}}$ \\ ${ }^{a}$ Laboratoire PACTE, Grenoble, France; ${ }^{b}$ Laboratoire CIRED, Paris, France
}

\section{Introduction}

In spite of one of the highest feed-in tariffs in Europe ${ }^{1}$ and growing policy objectives ( $7 \mathrm{GW}$ in $2010,{ }^{2}$ then $13 \mathrm{GW}$ in $2015,{ }^{3}$ and $23 \mathrm{GW}$ in $2020^{4}$ ), wind power capacity has remained limited in France. In 2012, ${ }^{5}$ the overall installed capacity amounted to $7.5 \mathrm{GW}$, placing France in fifth position in Europe. ${ }^{6}$ In other words, in spite of an ambitious policy support and abundant wind resources, France failed to develop wind power, as other European countries did under similarly favourable conditions. This suggests that our understanding of wind power potential and its conditions of emergence remain limited. The invocation of non-economic factors, such as local opposition or administrative barriers (procedures, delays, lack of coordination), casts only a partial light on the gap between national ambition and actual wind power development. The target of $23 \mathrm{GW}$ adopted by the French government, defined as a reachable objective and a potential per se, frames social and administrative processes as loci for barriers to wind power development. What such a 'potential' actually is remains unclear and hampers us in following and analysing the positive contribution of these processes to the emergence of local wind power capacities.

This paper proposes to depart from this approach to wind power potential and to draw attention to the institutional, political and geographical processes that underlie its construction. The academic literature has paid attention to the social and administrative processes of wind power development (Agterbosch et al. 2009; Aitken 2010a). In doing so, analysts depart from the restrictive framing associated with Nimby's idea (DevineWright 2005, 2009). The literature has emphasized the importance of community-based wind power development for developing projects (Walker \& Devine-Wright 2008) that allow for community benefits and environmental compensations (Aitken 2010b; Cowell et al. 2011), thus strengthening the 'trust' between local people and those groups, such as developers (Walker et al. 2010), that carry out these projects.

In the French context, the community-based development model is still emerging and does not yet play a role as important as it does in Germany, Denmark or the UK. Thus our assumption is that wind power potential does not pre-exist the deployment of wind turbines but emerges in the French context at the crossroad between an administrative tradition of landscape protection, planning approaches on the one hand and inherited socio-geographical configurations on the other. Analysis should not remain multi-factorial in a traditional sense, because the factors under consideration are drawn into evolution by the development of wind power: administrative officers and planners may evolve their practices, local networks and collectives may be reconfigured. So the challenge is to follow these dynamics and processes and their intertwining.

In order to do this, we have adopted a framework based on the ideas of striated space and smooth space (Deleuze \& Guattari 1980). These ideas have been mobilized in discussions on space, particularly in philosophy (Casey 1998; Antonioli 2003) and post-structuralist 
geography (Murdoch 1998; Doel 1999). However, attempts to endow them with an analytical reach in order to discuss empirical results are rare (Genosko \& Bryx 2006). Based on a strong empirical basis (4 case studies, 150 face-to-face interviews), our paper aims at describing and understanding the modes through which the weaving of landscape protection, planning approaches and inherited socio-geographical configurations underlie the emergence of wind power potentials in France. Our assumption is that wind power potentials are not only a quantitative contribution to an energy mix. They also differ qualitatively depending on the ability of wind power planning processes to endow inherited socio-geographical configurations with a new actuality that fits wind power development.

In the first part of the paper, we present our materials and method and discuss the reasons that wind power potential should not be reduced to a 'technological potential'. Using the ideas of striated space and smooth space, we then analyse the relational processes at work in four local cases studies of wind power development in France: Eure-et-Loir, Seine-etMarne, Aveyron and Narbonnaise. The third part discusses these processes and opens the debate on the role of inherited socio-geographical configurations and planning methods in the emergence of wind power potentials.

\section{Method and Materials}

A current view in the analysis of energy policies is that the 'technological potential', i.e. the capacity of a technology to contribute to an energy mix, pre-exists the deployment of the technology. For instance, renewable energies are assumed to be endowed with an intrinsic potential for development (Shove 1998). While this approach does not ignore political, social and environmental conditions, it fails to acknowledge the role of the processes through which renewable energies achieve their territorialization and emerge as a new reality. These processes are conceived as barriers to the achievement of the full 'technological potential'. In other words, because this intellectual framework defines the potential as an intrinsic attribute of the technology, the social dimension is framed as separated from the technology and as a 'barrier' (local opposition, administrative procedure) to the achievement of the 'technological potential'. Opposition thus becomes the default mode of the 'social' in dealing with the technological development.

The usual formalization of the 'technological potential' could be compared with Russian nesting dolls. This is at least suggested by a recent survey of the literature about renewable energy costs, potentials and barriers (Verbruggen et al. 2010). ${ }^{7}$ Different categories of potential are defined, each corresponding to a state of development of the technology, from the smallest to the biggest: the market potential (the smallest state, under business as usual and forecast market conditions); the economic potential (once all - social and private - costs [negative externalities] and [co-]benefits, present and future, have been included in market prices); the socioeconomic potential (once behaviours, social structures and institutions are changed to better reflect sustainability dimensions); and the technological potential (obtainable by full implementation of demonstrated and likely-to-develop technologies or practices). On this view, any technology is characterized by a technical potential (the biggest doll) per se conceived as the highest level of development reachable by this technology. The quantitative hierarchy of potentials inevitably paves the way for framing technology development as a progression from market to technical potential, crossing the different levels of potential and overcoming the corresponding 'barriers' (market failure, institutional lock-ins, social barriers such as patterns of behaviour, acceptability issues) along the path of the potentials. 
Contrary to the idea conveyed by the metaphor, the potential of a technology cannot be pre-defined. The only potentials are those that are (co-)constructed. They depend on the economic, political and social frameworks that underlie the development of the technology. The hierarchy of potential is certainly not capable of guiding the pacing, direction of public action or the understanding of the process of development of a technology. To do so, another approach to technology, for instance, a heterogeneous network (Akrich 1988; Callon 1991; Latour 2005), is required. From this perspective, technologies (and their potential) emerge through social processes, through the experimentation in new relations and new compatibilities between humans and non-humans. Thus, for example, landscape issues or local oppositions are not external to wind power potential; they are issues or arenas through which wind power projects (and potential) find a collective and shared dimension. These arenas, and so the potential, are highly dependent on the institutional frameworks that underlie wind power policy at different levels.

We propose using the ideas of striated space and smooth space (Deleuze \& Guattari 1980) as a conceptual framework for analysing the articulation between wind power planning processes and the emergence of wind power (potential); and also, in order to consider the role of inherited socio-geographical configurations in these processes, to look at the works of Gérard Chouquer (2000, 2007), especially the idea of transformission.

The model of striated space is a fabric, with its structure (weaving loom, vertical and horizontal threads, weaved perpendicularly), its limits (the fabric can be infinite in length but not in width) and its dynamic order (elements have different functions, the warp thread is fixed and under tension, the weft thread is mobile and woven, passing above and beneath the warp). As an anti-fabric, felt is the model of smooth space. It implies no separation of threads, no intertwining, only an entanglement of fibres. In principle, it is infinite, open and unlimited in every direction. The two are very different conceptions and practices of weaving.

Normative wind power planning consists in a compilation of layers (sieve mapping) that adds up regulatory constraints (urban plans, heritage protection, etc.) and formal typologies of landscapes. Sieve mapping allows planners to devise zones compatible or incompatible with wind power development. It generates a stratified space (superposition of constraints layers) in which spatial differentiation and wind power potential result from a quantitative operation (number of constraints faced by the developer). In doing so, planning freezes part of existing landscapes into heritage categories (the warp) and aims at composing wind power landscapes by (metaphorically) weaving wind power (the weft) between the preserved threads of heritage. It is as if the administration were using a gigantic landscape loom. The technology is shuttled back and forth and progresses in round trips. Most importantly, warp (heritage) and weft (the technology) threads are kept apart as separate entities, whose weaving produces new landscapes of energy. This stratified space model conveys the promise of a peaceful world where the past and the new can be kept apart, as distinct temporalities.

Gérard Chouquer's work on the analysis of landscape formations over long periods of time helps us in understanding in detail the limited reach of the idea of striated space. It confronts two limits: the first is the belief in the continuous preservation of spatial formations as the condition of their transmission through times (what Chouquer calls the planimetric approach); the second is an understanding of time as a stratified structure in which the past is the underground and generates the present, which is at the surface (i.e. the stratigraphic approach). These conceptions of space and time condition the process of transmission according to fixedness and convey an excessively decisive influence of previous periods of time on later ones. This echoes the difficulty of a normative wind power plan to depart from landscape protection and to explore inherited socio-spatial 
configurations in relation to the emergence of new energy landscapes. Chouquer proposes the idea of transformission (i.e. a bundling together of 'transformation' and 'transmission') in order to follow landscape recompositions and especially how their configurations still live on through the heterogeneity of their historical uses.

This transformative approach to landscapes calls for a new 'art' of planning in order to surmount a vision of territory and landscape as fixed elements. The concept of 'smooth space' suggests that territories and landscapes are an entanglement of fibres. Territories and landscapes are not dissolved or denied; they are rolled back and forth and constantly recomposed in order to produce a new felt. In this sense, the idea of smooth space is close to the idea of a relational space, but it enlarges the latter to include non-causal relations: inherited configurations, carefully processed and recomposed through planning processes, may incidentally play a role in the emerging landscapes of the energy transition. This paper is based on previous work begun in 2005 about the emergence of the French wind power policy. It gathers together four case studies selected after a survey of wind power processes in several French regions so as to identify exemplary processes. Each case study has been published separately (Nadaï \& Labussière 2009, 2010, 2013, in press) ${ }^{8}$ and carries out an analysis through a specific lens (i.e. biodiversity protection, landscape protection, local opposition, etc.). We focus here on the role played by planning processes in the construction of local wind power potentials. The work is based on written and graphic documents, field observations and face-to-face qualitative interviews (150 for the 4 case studies) with state ministerial fields (e.g. environment, equipment, industry and energy), local mayors, proand anti-'wind' NGOs, inhabitants, territorial organizations such as the natural regional parks, wind power developers and private landscape firms or environmental experts engaged in the development of wind power projects. It is also based on participant observations, such as accompanying farmers at work on their land or accompanying administrative officers during their fieldwork. The interviews were conducted in several campaigns between 2005 and 2009.

\section{Wind Power Potentials in the Making: The Second Life of Inherited} SocioGeographical Configurations

In France, wind power development has raised a double issue of decentralization (Nadaï 2007; Nadaï \& Labussière 2012). For French energy policy, the issue is how to bring wind power projects into politics at the local level, so as to build acceptance in a context in which wind power policy is based on economic incentives and private developers. In French landscape policy, wind power development points to the need for departing from the 'State landscape' (Nadai \& Labussière 2014) - an administrative, visual and patrimonial approach to landscape protection - in order to include public consultation and people's experience of their landscape in the composition of wind power landscapes.

In the French case, planning processes play a key role in the making of local wind power potentials (Nadaï \& Labussière 2009, 2010, 2013, in press). The first wind power planning instrument (wind power development zone (WPDZ)) was implemented very late, in 2007, when wind power development had already been supported by a feed-in tariff for seven years. In the meantime (2000-2007), civil servants and local populations were put under intense pressure to accept project developments by private developers. As the administrative tradition of landscape protection is very centralized, the first generation of wind power planning was quite normative and, with only a few exceptions, did not take into account local politics in relation to wind power developments.

In the following case studies, the inherited socio-geographical configurations appeared to play a key role in the emergence of new energy landscapes, in conjunction with planning 
and siting processes, spatial characteristics and wind power issues. In this paper, we bring these cases studies into a comparative and renewed (striated vs. smooth space) perspective, looking at the presence and the role of these configurations in the making of wind power potential.

\section{Massive and Uncontested: Wind Power Development in the Beauce Open Field (Eure-et-Loir)}

The first case study deals with wind power development in the Eure-et-Loir (Nadaï \& Labussière in press), a department characterized by the presence of open fields, the Cathedral of Chartres and one of the largest installed wind capacities in France (444 MW approved in 2007, $705 \mathrm{MW}$ in 2013).

The land is covered, owned and managed by industrial farming. Interviews with various actors in this area attested to a conception of wind power as an affair of private business.

Wind power projects allegedly (exclusively) concerned land and turbine owners: farmers and private wind power developers. There is no opposition to wind power, even in the most equipped areas.

The local governance is highly intertwined with industrial farming. Most village mayors and town councillors are former farmers, nowadays big industrial farmers. Some councils even manage wind power projects in order to regulate possible conflicts of interests among farmers, eventually endowing projects to a shared dimension. In one of the municipalities, this 'agricultural' governance went quite far in its management of the environmental issues. The water table had been polluted by industrial agriculture to the extent that tap water had no longer been drinkable for several years. Allegedly, this had caused no tension or complaint in the village because the inter-communality decided to deliver bottled drinking water, for free, on a weekly basis - in order to compensate for the pollution. In both cases, impact on the landscape and on the environment has raised only minor complaints or opposition in these large spaces devoted to and owned by private industrial agriculture. In other words, landscape did not seem to raise a public issue, except for the administration. The case of Eure-et-Loir is illustrative of this. Historically, the French approach to landscape protection was based on the ideas of common good (heritage monuments or sites) and visual protection. In the Eure-et-Loir, this approach translated into a wind power planning scheme mainly concerned with the views from and to the cathedral of Chartres, a monument classified as part of the UNESCO World Heritage. In 2005, the first cartographic representation presented the cathedral in the form of geometric cones radiating into the countryside and supposed to map areas of visual protection (no wind power development in these cones). This plan exemplifies what a striated space is: a space produced through the addition of regulatory constraints with a will to preserve the past, opening tech-

nological deployment in the gaps.

In practice, the proliferation of industrial wind turbines generated such a web of farreaching visual relations in the countryside and with existing monuments that such traditional landscape protection became unmanageable. This enticed civil servants to engage in fieldwork so as to develop a situated experience of the presence of the turbine and sharpen a definition of emerging landscape entities. Progressively, the perception of landscape relations and the language of sensation came to relay the traditional 'perimeters of visual protection' in the approach to landscape protection. Fieldwork and perceptual experience under the form of a smooth space opened the administration to a relational perspective on the wind power landscape and laid foundations for new landscape categories (e.g. 'traditional' and 'wind power' Beauce landscape) and aesthetic codes. 
These categories and codes underlay the devising of a new wind power plan. New cartographic forms, such as 'wind power basins' and 'breathing spaces', were substituted for traditional protection perimeters and testified to the role of new landscape sensations, such as visual density and visual relief, in the approach to landscape planning. This relational perspective on landscape restores the ability of the administration to have a say in wind power development and pursue its mission of preserving the landscape as a public good. Nevertheless, this second-generation plan is not radically innovative since it still keeps the public at a distance: no public consultation on these new orientations has been undertaken and the administration is not listening to the particular concerns of the population about the landscape. In this context, the socio-geographical configuration shaped by a market-driven farming seems to be suitable for a capitalistic wind power development model.

\section{Highly Controversial: The Wind Power Development in the Paris Region (Seine-et-Marne)}

Seine-et-Marne is a neighbouring department of the Beauce. Its territory is also occupied by industrial agriculture, but farms are smaller than that in the Eure-et-Loir. It is situated in the south-eastern Ile-de-France region, one hour distance from Paris. The population is both rural and neo-rural, i.e. former urbanites who have left the city in search of a better quality of life. Wind power development is faced with lively opposition (11 projects underway, 7 projects stopped, 10 anti-wind power NGOs in 2010, and 6 MW approved in 2013). Opposition to wind power has been described by outsiders (i.e. private developers) as rooted in Nimby concerns and neo-rural population. Our analysis adopts an insider's perspective on the construction of local opposition. We follow the development of networks of so-called 'opponents' to wind power in the village of Ventville ${ }^{9}$ in the Southern part of Seine-et-Marne.

Before wind power, Ventville was famous for its ambiance. Agricultural families used to work as community organizers. Farmers and their families were personally committed to building a public life (the warp) that could be shared with the other inhabitants (the woof). Farmers' families used to lead local NGOs and had, through generations of mayors, been in charge of local politics. Being the mayor relied on the everyday art of working with (and for) neighbours, who are also the voters. It is the art of weaving a continued 'agricultural' governance and public life into the diversity and singularities of private concerns. Confidence was continually produced by weaving this coherent social fabric. In the area of Ventville, the loom also produced another high-quality fabric: a shared agricultural space, called the 'plain'. The 'plain' is a continuous entity of fields. These fields are free of infrastructure (i.e. high voltage lines, motorways) and so easy to plough, crop and, eventually, switching parcels of land to consolidate more continuous and coherent individual parcels. The continued agricultural quality of the 'plain' has been maintained for generations of farmers (the warp) by individual management of each parcel (the woof) and by their periodic exchange through land consolidation. In both instances, the common good and a social fabric resulted in threads running lengthwise and private concerns progressing in threads running crosswise.

In 2003, the arrival of wind power started to rend this social fabric. A project was initiated by two farmers on their own lands, in the 'plain'. As one of them was the mayor of the village and omitted informing the other inhabitants, a conflict of interest ensued. The first inhabitants to hear of the project, Mr and Mrs Why did not have a predefined stand on wind power. They took a one-day trip to experience how it felt to be in a wind power landscape (at Janville, 100 kilometre from Ventville). Later, during a city council meeting, they advised the mayor and two of his assistants to go there and experience for 
themselves a wind power landscape. The mayor and his assistants did so, but maintained their refusal to open a public debate about the Ventville project. Mr and Mrs Why organized a consultation at their house, where people could come, read documentation about wind power, talk and eventually sign a petition asking for a referendum. Yet the municipality had already submitted a project for a WPDZ for administrative approval and the mayor did not follow up on the petition. He put forward the democratic legitimacy of his mandate as a basis for deciding on the project. Inhabitants asking for a public debate about the project had no choice but to become engaged in the local opposition to wind power. In the end, growing tensions led to ruptures in long-established social networks and to social violence, such as tags, insults and muggings. The perspective of a wind power project also affected the traditional management of the 'plain' because of the uncertainties and constraints generated by the devotion of parcels to fixed infrastructures (i.e. wind turbines, underground cabling). Thus, after several attempts to open the process to public consultation and to reactivate the traditional weaving loom (sharing the landscape sensation with the city council, home-made consultation, petition for a referendum), some inhabitants and farmers insisted upon an enlarged community perspective. The dispute moved to electoral ground in 2008. For the first time in the history of Ventville, the mayor faced an opposition list in the local election. He was re-elected and publicly framed his success as the sign of political support to the wind power project.

In this context, the late departmental (Seine-et-marne) wind power planning exacerbated the strategic dimension of local conflicts. The local administration undertook a usual sieve mapping exercise that directed the potential wind power development towards three sectors on the margins of Seine-et-Marne. These sectors included Ventville, where landscape sensitivity to wind power development was supposed to be low. Such a framing increased local tensions since the first wind power projects to be authorized would turn potential sectors into actual wind power zones.

Local opponents networked so as to coordinate areas of vigilance in the south of SeineetMarne. A myriad of local NGOs, akin to fibres progressively interconnecting with one other, entangled their resources on a new scale and engaged in collective action. Such a meso-territorial level allowed this new community to seize the sectors targeted by the administration, to discuss more than a project and to politicize French wind power policy. This smooth space was aimed at renewing the striated relations of the 'agricultural' governance in order to foster a debate on landscape protection and wind power policy on a scale congruent with landscape issues. As a felt, this new web did not imply a categorization or a separation of threads and was not limited in space. The politicization of wind power policy had a chance to proceed and progress gradually over the frontiers of the IledeFrance region.

The case of Ventville underlines how hard it can be for a municipality to endow a wind power project with a collective dimension. At the national level, the French government asserts that wind power is endowed with public interest. Yet, for many reasons, the public dimension of wind power is not a given. ${ }^{10}$ It must be reconstructed on a projectby-project basis. As the potential of French institutions to sustain this reconstruction is currently weak, the social re-composition induced by wind power projects at the local level plays a key role. The 'agricultural' governance in Ventville was not in a position to renew an inherited community model in order to address collectively wind power issues and claims, and so contributed to building its own opposition.

\section{WPDZ Governance and the Making of Wind Power Landscapes in the Aveyron}

Aveyron (South West France) is one of the French departments with the best wind potential. Wind power development started in the Aveyron in 1999. No wind power planning 
whatsoever was in place at that time. In order to cope with the increasing number of projects submitted for approval, the local administration decided to set an inter-services platform (in 2000) and to start devising a planning scheme. At that time, the Regional Natural Park of the Grands Causses (RNPGC), a non-state actor, had suggested approaching wind power planning on the scale of the 'massifs'. The suggestion was that massif entities offered a framing that was more compatible with collective action - local mayors could collaborate in planning wind power - and made it possible to take better into account issues of landscape (far-reaching co-visibilities) and proximity. In 2000, the idea was discarded by the prefecture as being too complicated because massifs overlapped administrative divides. The local administration set aside this territorial approach because of the lack of landscape analysis capable of objectifying these massifs entities.

The outcome was the first wind power planning scheme issued in 2005. The approach translated wind power issues into zoning through several operations such as the definition of landscape 'types' based on morphology and heritage values, the mapping of regulatory constraints and the addition of buffer zones so as to compensate for regulatory insufficiencies in the face of the exceptionally far-reaching co-visibilities imposed by industrial wind turbines. This gradual shift from a qualitative landscape issue to a zoning logic (favourable, unfavourable or negative) certainly answered to administrative instructors' need for rationality and objectivity in the face of the pressure from wind power developers (Nadaï \& Labussière 2009).

The development inside the favourable zones was left unplanned and the pressure for project development was not really regulated. As the local administration was unused communicating figures about projects under consideration (accepted, under acceptance, refused), word-of-mouth made up for the lack of information. Inhabitants of a hamlet in the Massif of Lévezou started to go door-to-door in order to cross-reference information. In doing so, they joined private concerns into a network covering the Lévezou, in which they quantified more than 200 wind turbines under consideration. In other words, wind power development was reaching a tipping point and compromising the entire massif of the Lévezou. In order to structure a resistance against wind power, they created a league ('Levezou in peril') so as to tie threads (heritage, proximity, landscape) that were kept separate by the administration. Thus the local opposition endowed massif entities with a political existence. They politicized massifs in the centre and the south of Aveyron in a new relational mode (smooth space) and reconfigured the access to wind power deployment. At the same time, landscape protection was facing the limits of the first wind power plan (e.g. co-visibilities between protected and authorized zones, obsolescence of landscape choices in the face of the rapid technological development of wind energy).

In 2006, WPDZ had just entered into implementation phase at the national level and provided the local administration with a legitimacy to revise the existing power plan. The Aveyron prefect was replaced. The new prefect imposed a temporary moratorium on wind power permits until all WPDZ could be turned into the administration by intercommunalities. New wind power basins were designed by coordinating the WPDZ processes on the scale of the massifs. Massifs, considered as landscape entities, were thus endowed with a political and relational existence. They provided an alternative weave, thus allowing the administration and the local actors to mend the 'holes' of the previous plan (i.e. 'free' blank zones) and to embroider enlarged wind power zones. This secondgeneration plan did not fully depart from the initial striated space but took advantage of a smooth space (i.e. massifs) as a transitional logic towards more open wind power governance.

In this process, the RNPGC supported intercommunalities through funding and the support of a landscape architect, provided they followed good practices in the devising of 
WPDZ (e.g. coordination on a massif scale, concerted decision process with local inhabitants). The process, which is still underway, has highlighted the unexpected potential of highlands (former commons used for grazing during the nineteenth century) at the other end of the massifs. The situation of these highlands limits the co-visibilities between the wind farms and the villages. Their status makes it easier for communities to share the financial benefits from wind power. Thus massif entities as a smooth space (i.e. relational, concerted and convenient) illustrate how a planning approach can reactivate inherited sociogeographical configurations so as to foster the emergence of a locally shared wind power potential.

The fate of the plateau of Larzac is paradigmatic of the role of smooth and striated spaces in this case study. In 1971, in the absence of any public consultation, the French State planned an extended military camp (striated space) on the plateau. The project triggered resistance from farmers, unions and the civil society (smooth space), and the project was abandoned in 1981. Nowadays considered as a testimony to pastoral landscape and as a symbol of the anti-militarist movement, the plateau has been classified as part of the national heritage (striated). This protection status was later translated into a 'sensitive landscape zone' (striated space) in the first wind power planning (2000). In the early 2000s, shepherds, who wanted to site a cooperative wind farm on the plateau, were faced with the close-knit fabric of the planning: they never succeeded in getting authorization for the project. After 2006, the RNPGC 'massif approach' paved the way for questioning this heritage status. One of the scenarios considered in the landscape study included, and discussed, Larzac as a potential area for wind power development (smooth space). This suggests that a relational approach could generate unexpected potential in places where historically strong community-based developments are reactivated.

\section{Innovative Wind Power Planning: The Experience of the Narbonnaise}

The Regional Natural Park of the Narbonnaise (RNPN) covers the eastern part of the Aude department (Languedoc-Roussillon, south-western France), which stretches along the Mediterranean coast just north of the Pyrenean mountains. Since the adoption of fixed tariffs in France in 2000, the Aude and especially the windy Narbonnaise have been pioneer sectors in the development of French wind power. By the end of 2007, 10 wind farms (110.2 MW, 92 windmills) were installed on the territory of RNPN and various planning documents (at the regional, departmental and RNPN levels ${ }^{11}$ ) had already attempted to regulate wind power development.

In 2002, the area included some of the allegedly worst examples of wind farm siting in France and the RNPN was faced with an increasing number of wind power projects. It decided to commission a landscape company to devise a planning scheme for wind power. The RNPN wind power charter was adopted by the RNPN steering committee in 2003. This planning process brought together mayors, wind power developers, NGOs and ministerial field services in a consultation. The aim was to set the boundaries for favourable and unfavourable envelopes for wind power developments, together with specific landscape recommendations ('re-powering', ${ }^{12}$ densification, dismantling). The resulting envelopes were thus sectors in which it was felt acceptable to set wind farms. Surprisingly, they mainly targeted small plateaus, such as the Plateau de Haute Garrigue, which overhang villages.

This planning was designed as a resource for wind power developers. It provided them with areas in which project development was thought to be acceptable as well as with recommendations for approaching the siting of wind farms in these areas. The plan did not prescribe any specific design for siting but enticed developers to go into the field and experiment further with the likely recompositions of landscape relations that wind farms 
could induce (Nadaï \& Labussière 2013). Unlike much normative planning that produces a striated space (zoning) for the development of a generic technology, the Narbonnaise planning process maintained its openness to the multiplicity of situations. The wind power potential was therefore not only a technical one but also included territorial dimensions. Two processes are illustrative of these dimensions.

The first process pertains to a project sited in an envelope covering the Plateau de Garrigue Haute. In the 1990s, the Plateau de Garrigue Haute welcomed the first industrial wind farm in France. In 2010, this project was entering its repowering phase, again the first instance of such in France. Repowering provided an occasion for reconsidering the siting of the project and for articulating it on various scales and dimensions of the landscape. On the large scale, the landscape company in charge of the wind power charter emphasized the need to account for landscape relations (smooth space) and align the turbines with a major historical axis in the landscape, an old Roman road parallel to the seashore (i.e. Via Domitia). The plateau also emerged during the devising of the charter in the form of a piece of common land that was traditionally used by several farmers for sheep grazing ('biens sectionnaires'). The status and location of these common lands allowed the surrounding municipalities to depart from administrative frontiers (striated space), join and take part in siting turbines, which could be sited as one and coherent wind farm on the plateau (smooth space). On the small scale, the existing wind turbines provided birdwatchers with an opportunity to depart from categories of protected species (striated space) in order to follow and observe migrating birds strategies in relation (smooth space) to the presence of wind turbines (Nadaï \& Labussière 2010). Birdwatchers devised an innovative method called 'micro-siting' that allowed them to translate bird strategies into statistical and spatial representations congruent with planning categories, so as to negotiate the siting of turbines with wind power developers.

The second process relates to a neighbouring small plateau (Villesèque-des-Corbières), former grazing land that had been invaded by a garrigue cover. Boar hunters and protectors of raptors had joined together and set a up a European Life project ${ }^{13}$ in order to re-introduce sheep grazing and reopen the habitat for small game (such as rabbits and hares, which are prey for boars and raptors). As the French bird protection organization (the Ligue de Protection des Oiseaux) survey showed, the repowering on the Plateau de Haute Garrigue was likely to deprive raptors of part of their hunting territory. It was thus decided to use part of wind power benefits for environmental compensation (habitat creation for small game in a nearby area). Concretely, this meant an additional financial support for a shepherd in order to bring it to economically viable size. Thus wind power development not only contributed to ecological management and the revival of a traditional agricultural activity, but also was interwoven into traditional structures of landscape management (smooth space).

\section{Discussion}

The four case studies ultimately point to the issue of producing new landscapes of which wind power could be a part. These empirical processes illustrate the diversity of inherited socio-geographical configurations at stake in the emergence of wind power landscapes. In order to highlight their role, we have developed a multi-level analysis that encompasses French wind power policy, wind power planning processes and socio-spatial configurations.

As the case studies show, the deployment of wind power induces deep changes in landscapes and territories. It even sometimes modifies the way in which people live 
together in a place. This politicization of wind power generates new ad hoc collectives. In the French case, because of the institutional framework resulting from landscape and wind power policies (centralization, feed-in tariffs, private developers), collectives of emerging wind power landscapes are regularly set apart from wind power planning processes. This hampers exploring the options that these collectives could propose for wind power development. It induces conflicts around wind power development and makes the emergence of a wind power potential more difficult. Analytical perspectives, which reduce opposition to social protests, miss the relational perspective at work and the way in which opponent networks could contribute to the emergence of shared wind power potential.

The notions of striated space and smooth space enabled us to adopt this relational perspective and to account for the role of inherited socio-geographical configurations in a non-deterministic perspective: configurations participate in the emergence of a wind power potential, but there is no direct causality between a given configuration and a given potential. Rather, inherited socio-geographical configurations are re-actualized, reactivated in a new stream of connections and issues by current processes, which endow them with a renewed connectivity. This paves the way for an alternative approach to wind power potential, in which the 'technological potential' is not given in advance: social processes are endowed with a (potentially) positive contribution to the composition of this potential.

Our empirical results shed light on the processes of actualization of inherited sociogeographical configurations as well as on the role played by wind power plans in these processes. The case of Beauce illustrates how an 'agricultural' governance, whereby the organization of local economy and local politics is in the hands of industrial farming, can fit together with capitalist wind power. The striated space of this 'agricultural' governance intertwines with the smooth space of the globalized economy, provided 'agricultural' output (wheat grains or wind power) can be sold as commodities on a global market. Such an articulation allows industrial farmers to pull the Beauce territory and landscape into a new, partly de-territorialized actuality: commons (water table, landscape) vanish into market-driven coordination (bottled water, private business); wind power development is not faced with local opposition. In this context, the efforts of the local administration to regulate projects while keeping the public at a distance contributes to limiting the politicization of wind power and in opening this land to a capitalist wind power potential.

In the case of Seine-et-Marne, the local 'agricultural' governance (striated space) faced a difficulty in enlarging the inherited community model to wind power issues and claims and so instigated its own opposition (smooth space). The late arrival of administrative (wind power, strategic) planning, geared to normative landscape protection (striated space), worsened tensions. It turned local conflicts over wind power projects into decisive processes for the becoming of landscape zones (wind power basin/or not). The networking of oppositional NGOs and their radicalization (smooth space) sustained the emergence of a 'wind power standpoint' at a meso-territorial level. The resulting wind power potential is controversial because its sets aside inherited configurations and leaves them unaccompanied in their attempt to endow wind power projects with a collective dimension.

In the case of Aveyron, an early normative wind power plan (striated space) failed to regulate the development of wind power and generated massive opposition at the local level. This opposition, in conjunction with an evolution in planning approach (implementation of WPDZ, change in local prefect), resulted in the emergence of massifs as new political entities (smooth space). By contrast to the case of Seine-et-Marne, the adjustment to the planning approach and its realignment with massifs led to more open 
governance. The support of the RNPGC, including the help of a landscape architect, allowed the reactivation of inherited configurations and discussion of the impacts and benefits of wind power projects so as to pave the way for a negotiated wind power potential.

Last but not least, in the Narbonnaise, administrative planning (striated space) led to publicized siting-failures, in which wind power siting conflicted with inherited landscape norms (striated space), in part triggering local opposition. The switch to relational planning allowed local actors to re-articulate wind power development with the smooth space of landscape configurations on a plurality of scales: socio-historical (actualizing plateaus as former commons), experience (plateau with limited co-visibilities and with villages) and practice (hunting, sheep farming/grazing, sharing of wind power benefits). The process is sustained by the emergence of unforeseen collectives (hunters, bird watchers, nature protectors and wind power developers) (smooth space). Repowering, as part of a financial logic (the smooth space of global economy), re-actualized the striated space of actual wind farms (aerolic grid, pylons). Birdwatchers used this spatiality as an infrastructure (pylons, distances, rotating turbines) for mapping the smooth space of bird cognition and to realign the siting of new wind turbines with existing landscape relations on a multiplicity of scales (Roman axis, seashore, migration corridors). The process paved the way for a negotiated and conditional wind power potential: a negotiated potential that is conditional upon a follow-up of its impact on birds.

Focusing on inherited configurations is a means of following the emergence of a relational perspective in wind power development and planning processes. It is a way of analysing the extent to which planning can renew its approach to landscape and territory. The previous case studies suggest that a deep renewal of planning methods is called for in order to account for what may be called the unexpected potential of new collectives in emerging energy landscapes. This confronts planners with a huge challenge in the French context that of decentralizing the policy of landscape protection.

In the case of the emerging wind power landscapes, and as suggested by the transformative approach of Gérard Chouquer, obduracy and change are two sides of the same coin. Wind power potential is a multi-temporal object. This point is discussed in our paper in terms of three different ideas. First, wind power potential is composed through the interweaving of long-term processes (i.e. inherited socio-geographical configurations) and project approaches, two temporalities usually ignored by planning methods. We have illustrated how inherited socio-geographical configurations can provide current project processes with spatially oriented patterns (i.e. Via Domitia) or rules for space sharing (i.e. common lands). We have also showed that the reactivation of these configurations is highly dependent on the capacity of planning approaches to suspend current norms in order to sustain a multi-scalar/multi-temporal investigation. Second, as Gérard Chouquer has stated heritage may result from an historical process through which the social values attributed to landscape configurations are revised, even reversed (from negative to positive). This happened in the case of the administration of Eure-et-Loir when, after decades of indifference to the Beauce agricultural landscapes, it decided to preserve them from wind power development. Similarly, the administration of Aveyron when it protected the Plateau of Larzac known as a region of lively opposition to the French State in the 1970s. Third, wind power potential never seems pure (striated space or smooth space), but rather emerges between both perspectives, superimposed or weaved together to different degrees. From this point of view, in the French context, the double issue of decentralization in energy policy and landscape protection has generated a restrictive approach to the wind power development (private developer, private individual engagement) (striated space). Despite attempts to politicize wind power projects at the local level (smooth space), this 
legacy still hinders the deployment of French wind power policy and the emergence of community-based models.

\section{Conclusion}

When developed on a significant scale, wind power induces massive mutations in our landscapes and territories. These changes impact on the ways local populations relate to biodiversity, landscapes and places. They foster the emergence of new collectives, which contribute in carrying out these changes. This relational work has generated important tensions in the French context, where landscape protection is traditionally centralized and limited attention is paid to local opposition.

This paper explores the way in which these recompositions are part of the emergence of wind power potentials. The empirical evidence stemming from our case studies confirms that wind power technology, like any other technology, is not endowed with a potential per se. Wind power potentials do differ - 'capitalistic', 'controversial', 'negotiated', 'conditional' - depending on planning processes and inherited configurations. Depending on these, one installed megawatt may be associated with intense conflicts or unexpected synergies. An original result of this paper is to describe the emergence of unexpected wind power potentials: qualitatively, as illustrated by the work of innovative planning processes in their capacity to create shared wind power potentials previous areas of conflict; quantitatively, when the art of planning with inherited configurations discovers new zones and alternative scenarios of wind power development. Issues are closely intertwined and priorities of action can hardly be ordered otherwise than through situations and processes. Hence the hierarchy suggested by the metaphor of Russian nesting dolls - deregulate market, internalize externalities, develop participative institutions - is of very limited value as a guideline for public policies.

The emergence of energy landscapes is largely driven by national policies and technological options. In the case of wind power, however, the emergence of new collectives attests to the progressive affirmation of 'wind power standpoints', which also contribute to shaping these new landscapes. Such standpoints and collectives are crossroads from which we can explore the articulations between inherited configurations and project approaches. Accounting for these collectives, not as 'barriers to' but as 'factors for' the emergence of wind power potentials, is a decisive step in understanding the paths that lead towards renewable communities.

\section{Funding}

This work was undertaken with the financial support of the Conseil Français de l'Energie, the French Ministry for the Environment (MEDAD - Program PDD Paysage et Développement Durable), the French Agency for the Environment and the Energy (ADEME), the Region Ile-de-France (R2DS), and the French ANR (Projet Collener)

\section{Notes}

${ }^{1}$ The French feed-in tariff was $82 €$ MWh in 2012 for onshore wind power for ten years, with progressive reduction over five years. This value has remained more or less the same since the first tariff order in 2001.

${ }^{2}$ Minefi (2002). Programmation pluriannuelle des investissements de production électrique. Période 2000-2010, 8 p.

${ }^{3}$ Minefi (2006). Programmation pluriannuelle des investissements de production électrique. Période 2005-2015, $105 \mathrm{p}$.

${ }^{4}$ Meeddat (2007). Rapport de synthèse du Groupe 1, Grenelle de l'environnement, 27 septembre, Paris. 
${ }^{5}$ European wind energy association (2013) Wind in power. 2012 European statistics.

${ }^{6}$ France is placed after Germany $(31.3 \mathrm{GW})$, Spain $(22.7 \mathrm{GW})$, United Kingdom $(8.4 \mathrm{GW})$ and Italy $(8.1 \mathrm{GW})$.

${ }^{7}$ For instance, this hierarchy of potentials structures the approach of the IPCC mitigation potentials (see IPCCWGIII 2001, chapter 5).

${ }^{8}$ For more details about the methodology and fieldwork, see the cited papers.

9 'Ventville' is a pseudonym, chosen by the authors for the purposes of this paper.

${ }^{10}$ Including the fact that France has a low-CO2 electricity mix (dominance of nuclear energy).

${ }^{11}$ Région Languedoc Roussillon (2003) Schéma régional éolien, 4 volumes, Narbonne; PNRN, 2003 Charte du Développement Eolien - Projet de Parc Naturel Régional de la Narbonnaise en Méditerranée (2003), available (on 08/25/08), http://www.parc-naturel-narbonnaise.fr/en_actions/maitrise_de_1_energie_et_energies_renouvelables/charte_eolienne; Préfecture de l'Aude (2005) Plan de gestion des paysages de 1Aude vis-à-vis des projets éoliens, Narbonne.

12 'Re-powering' consists in dismantling an existing wind farm and in increasing its capacity by installing new, bigger and more powerful wind turbines. It is currently the way that countries such as Germany and Denmark increase their wind power capacity.

${ }^{13}$ http://aude.lpo.fr/life-consavicor/accueil.htm.

\section{References}

Agterbosch, S., Meertens, R. M. \& Vermeulen, W. J. V. (2009) The relative importance of social and institutional conditions in the planning of wind power projects, Renewable and Sustainable Energy Reviews, vol. 13, no. 2, pp. 393-405.

Aitken, M. (2010a) Why we still don't understand the social aspects of wind power: a critique of key assumptions within the literature, Energy Policy, vol. 38, no. 4, pp. 1834-1841.

Aitken, M. (2010b) Wind power and community benefits: challenges and opportunities, Energy Policy, vol. 38, no. 10, pp. 6066-6075.

Akrich, M. (1988) La recherche pour l'innovation ou l'innovation pour la recherche? Le développement du photovoltaïque en Polynésie, Culture Technique, no. 18, pp. 318-329.

Antonioli, M. (2003) Géophilosophie de Deleuze et Guattari (Paris: L’Harmattan).

Callon, M. (1991) Techno-economic networks and irreversibility, in: J. Law (ed.) A Sociology of Monsters, Sociological Review Monograph, pp. 132-164 (London: Routledge).

Casey, E. (1998) The Fate of Place. A Philosophical History (Berkeley: University of California Press).

Chouquer, G. (2000) L'étude des paysages. Essai sur leurs formes et leur histoire (Paris: Editions Errance).

Chouquer, G. (2007) Quels scenarios pour l'histoire du paysage? Orientations de recherche pour l'archéogéographie, préface de Bruno Latour (Porto: Centro de Estudios Arqueologicos das Universidades de Coimbra e Porto).

Cowell, R., Bristow, G. \& Munday, M. (2011) Acceptance, acceptability and environmental justice: the role of community benefits in wind energy development, Journal of Environmental Planning and Management, vol. 54, no. 4, pp. 539-557.

Deleuze, G. \& Guattari, F. (1980) Capitalisme et schizophrénie Mille plateaux (Paris: Les Éditions de Minuit).

Devine-Wright, P. (2005) Beyond NIMB Yism: towards an integrated framework for understanding public perceptions of wind energy, Wind Energy, vol. 8, no. 2, pp. 125-139.

Devine-Wright, P. (2009) Rethinking NIMBYism: the role of place attachment and place identity in explaining place-protective action, Journal of Community \& Applied Social Psychology, vol. 19, no. 6, pp. 426-441.

Doel, M. (1999) Postructuralist Geographies. The Diabolical Art of Spatial Science (Edinburgh: Edinburgh University Press).

Genosko, G. \& Bryx, A. (2006) After informatic striation: the resignification of disc numbers in contemporary Inuit popular culture, in: I. Buchanan \& G. Lambert (eds) Deleuze and Space, pp. 109-125 (Edinburgh: Edinburgh University Press).

IPCC-WGIII. (2001) Climate Change 2001. Mitigation (Cambridge: Cambridge University Press).

Latour, B. (2005) Reassembling the Social, an Introduction of Actor-Network Theory (Oxford: Oxford University Press).

Murdoch, J. (1998) The spaces of actor-network theory, Geoforum, vol. 29, no. 4, pp. 357-374.

Nadaï, A. (2007) 'Planning', 'siting' and the local acceptance of wind power: some lessons from the French case, Energy Policy, vol. 35, no. 5, pp. 2715-2726.

Nadaï, A. \& Labussière, O. (2009) Wind power planning in France (Aveyron): from State regulation to local experimentation, Land Use Policy, vol. 26, no. 3, pp. 744-754

Nadaï, A. \& Labussière, O. (2010) Birds, turbines and the making of wind power landscape in South France 
(Aude), Landscape Research, vol. 35, no. 2, pp. 209-233.

Nadaï, A. \& Labussière, O. (2012) Le paysage éolien, décentralisation énergétique et paysagère, in: C. Bouneau, D. Varaschin, L. Laborie, R. Viguié \& Y. Bouvier (eds) Paysages de l'électricité, pp. 185-202 (Bruxelles: Peter Lang).

Nadaï, A. \& Labussière, O. (2013) Playing with the line, channeling multiplicity. Windpower planning in the Narbonnaise (France, Aude), Environment and Planning D, vol. 31, no. 1, pp. 116-139.

Nadaï, A. \& Labussière, O. (in press) Wind power and the emergence of the Beauce landscape, Eure-et-Loir, France, Landscape Research. doi:10.1080/01426397.2013.784732

Shove, E. (1998) Gaps, barriers and conceptual chasms: theories of technology transfer and energy in buildings, Energy Policy, vol. 26, no. 15, pp. 1105-1112.

Verbruggen, A., Fischedick, M., Moomaw, M., Weir, T., Nadaï, A., Nilsson Lars, J., Nyboer, J. \& Sathaye, J. (2010) Renewable energy costs, potentials, barriers: conceptual issues, Energy Policy, vol. 38, no. 2, pp. $850-861$.

Walker, G. \& Devine-Wright, P. (2008) Community renewable energy: what should it mean? Energy Policy, vol. 36, no. 2, pp. 497-500.

Walker, G., Devine-Wright, P., Hunter, S., High, H. \& Evans, B. (2010) Trust and community: exploring the meanings, contexts and dynamics of community renewable energy, Energy Policy, vol. 38, no. 6, pp. 26552663. 